"Impact of transport infrastructure on firm performance: case study of Cuu long delta area, Vietnam"

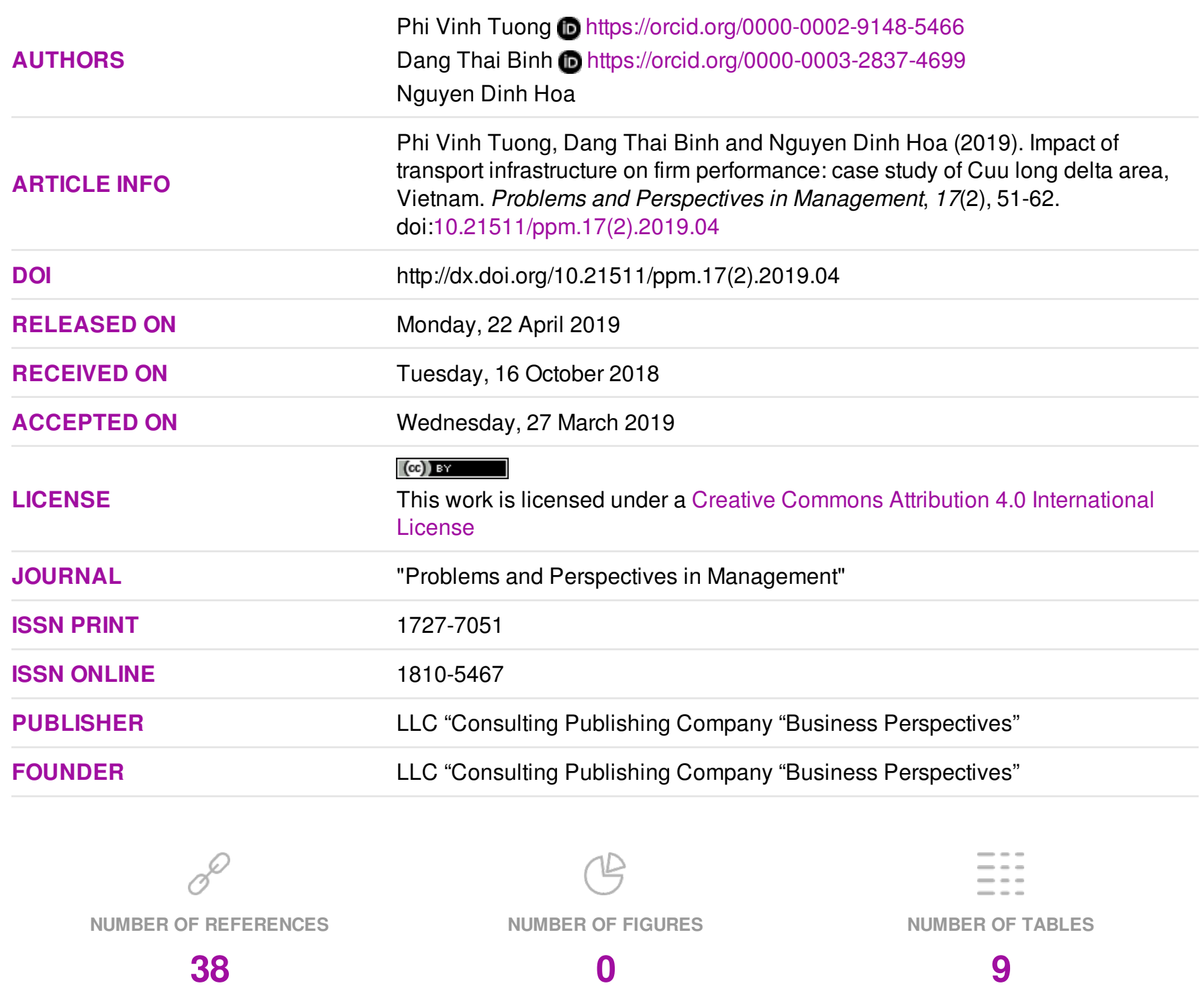

(C) The author(s) 2023. This publication is an open access article. 


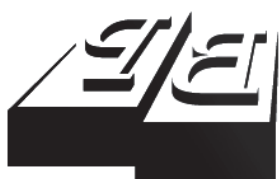

BUSINESS PERSPECTIVES

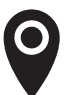

LLC "CPC "Business Perspectives" Hryhorii Skovoroda lane, 10, Sumy, 40022, Ukraine

www.businessperspectives.org

Received on: $16^{\text {th }}$ of October, 2018 Accepted on: 27th of March, 2019

(C) Phi Vinh Tuong, Dang Thai Binh, Nguyen Dinh Hoa, 2019

Phi Vinh Tuong, Doctor, Deputy Director at Institute of Social Sciences Information, Vietnam Academy of Social Sciences, Vietnam.

Dang Thai Binh, Doctor, Researcher at Institute for India and Southwest Asian Studies, Vietnam Academy of Social Sciences, Vietnam.

Nguyen Dinh Hoa, Doctor, Researcher at Vietnam Institute of Economics, Vietnam Academy of Social Sciences, Vietnam.

\section{(ㄷ)(ㄱ)}

This is an Open Access article, distributed under the terms of the Creative Commons Attribution 4.0 International license, which permits unrestricted re-use, distribution, and reproduction in any medium, provided the original work is properly cited.

\title{
IMPACT OF TRANSPORT INFRASTRUCTURE ON FIRM PERFORMANCE: CASE STUDY OF CUU LONG DELTA AREA, VIETNAM
}

\begin{abstract}
Transport infrastructure plays an important role in promoting the socio-economic development in most countries. In particular, the development of road infrastructure is the basis for promoting enterprises development through expanding market access, lowering logistics cost and inputs cost, etc. The focal point of this paper is to estimate the impact of road infrastructure on firm performance through an empirical research in Cuu Long delta area, Vietnam. By applying the econometric models, the results from this study show that the positive relationship between road infrastructure and firm performance in Cuu Long delta area, and that the level of impact is different across business sectors.
\end{abstract}

\section{Keywords}

\section{JEL Classification}

road infrastructure, firm performance, enterprises, Cuu Long delta area, economic development

\section{INTRODUCTION}

Economic growth and development in every region of each country depends on the development of the enterprises. Enterprises competitiveness is the basis of growth and sustainable development. Competitiveness of enterprises is governed by two main important factors, i.e. internal factors and external factors. The internal factors reflect the internal problems of the business, related to the way of organizing production and business. External factors form the business environment of the enterprises, including the policy framework regulating the operation of enterprises, energy infrastructure, telecommunication infrastructure and transport infrastructure. In particular, the development of transport infrastructure plays an important role with the development of enterprises.

For the enterprises, increasing shipping time leads to an increase in production and business costs due to (1) longer transport process leading to an increased risks of broken products; (2) increased storage costs due to accumulated inventory to ensure that the production process is not interrupted by the circulation process; (3) transportation costs, due to fuel loss and depreciation of vehicles. Therefore, high quality and convenient transportation infrastructure will ensure the transportation facility more quickly and above all will help in businesses to reduce transportation costs.

Investment in the development of road and transport infrastructure is one of the significant criteria for the growth and smooth running of businesses, which will reduce the transportation costs from raw material areas 
to factory, as well as from factory to market. The developed road and transport infrastructure helps businesses to have access to further markets (Albarran, Carrasco, \& Holl, 2011). For businesses, in addition to factors such as market entry costs and firm size, transportation costs are also an important factor affecting export activities of domestic enterprises. Reducing domestic road and transport costs is the basis of increasing the probability of having an additional domestic enterprise involved in export. Research results suggest that developing economies, which are characterized by poor road and transport infrastructure, need to invest in transport infrastructure if they want to promote trade and access to key international markets.

Watson, Farley, and Williams (2009) have demonstrated the role of road and transport infrastructure in enterprise development, through the impact channel, as transportation costs. Improving the quality of transport infrastructure is like smoothing the flow of the economy, facilitating good circulation of goods. Good quality road and traffic infrastructure system will minimize transportation costs, as well as losses in the process of importing raw materials (input costs). It also minimizes the risk of product distribution to the market (affecting output costs). In other words, poor quality transport infrastructure is responsible for underperforming production process, as well as inefficient goods circulation, and thus inhibits economic growth.

In Vietnam, transport infrastructure in general and road and transport infrastructure in particular have improved significantly, meeting partly the development requirements of the economy. Most notable is the improvement and contribution to the development of the economy of road and transport infrastructure (VCCI, 2012; Garcia-Puente, M. Paloma Alonso, 2013).

In addition, the investment in the development of transport infrastructure is uneven across regions, especially in slow-growing regions like Cuu Long delta area. It leads to road infrastructure development in the Cuu Long delta area still has many shortcomings, such as lack of uniformity in planning, low quality, lack of connectivity, poor transportation services. In particular, the development of transport infrastructure is the reason for inhibiting the development of the region.

Cuu Long delta area is characterized by a slow-growing region, with intermittent river systems, the advantage of developing agricultural sector and waterway, which are the absolute advantages of the region. Therefore, choosing Cuu Long delta area for a case study that will specify the impact of transport infrastructure on enterprises in general and on enterprises in business sectors in particular. In this study, to estimate the impact of road infrastructure on firm performance, the authors start with Cobb-Douglas production function, a conventional model in the previous researches (Escribano et al., 2010; Wan \& Zhang, 2017). Then, the authors transfer into translog of Cobb-Douglas function. Ordinary least squares (OLS) model has been used for eveluating the impact of road infrastructure on firm performance in the region. Besside, the authors use VAR Granger causality model to investigate the causal impact of road infrastructure on firm performance. By using this method, the research wants to find the answer whether road infrastructure is the cause of firm performance or not.

This research will help local, regional policymakers, as well as central government, to have better understanding on the impacts of road infrastructure development in an undeveloped region with a maze of rivers, swamps and islands.

\section{LITERATURE REVIEW}

The role and impact of transportation infrastructure is an interesting subject of many scholars around the world, which plays an important role in the economic growth of the country and the region such as poverty reduction, trade growth, helped transform the model towards sustainability and green growth (Fay et al., 2010; LozanoOyola et al., 2012; Márquez-Ramos, 2015). The development of transport infrastructure has also caused much environmental issues than any economy has to trade off when pursuing the economic growth. 
UNDP (1992) pointed out that infrastructure improvement plays a key role in assisting development and achieving sustainable economic growth. The study suggested that the development of infrastructure should be synchronized in both hard and soft infrastructures in order to enable the economy to achieve the development goals. Hard infrastructures (e.g. transport, urban, energy and telecommunications infrastructures) play a significant role in fostering the industrialization and modernization process. Irrigation and energy infrastructure facilitate the modernization of rural areas. Synchronous development of various types of hard infrastructure is considered as the foundation for the success of some countries in the world such as Japan and Korea.

In addition, enhancing the quality of infrastructure will boost economic growth, eliminate poverty and reduce inequality (e.g., Helpman \& Krugman, 1985; World Bank, 1994; Escribano et al., 2010; Mitra et al., 2016; Wan \& Zhang, 2017). Yoshio and Nakahigashi (2000), Calderon and Serven (2004), Kingsley (2004) confirmed the above positive effects of infrastructure, despite the scope of these studies was a Southeast Asian country or the world's economies or concentrated in the group of emerging economies. In a different approach, Fay et al. (2010) show that the lack of infrastructure is leading to limiting economies to take advantage, exploiting the potential for economic growth and development. Although many countries are well aware of the role of various infrastructures, they face many difficulties, such as huge infrastructural investments, budget constraints, and institutional constraints. These limits the countries in mobilizing external resources for development.

For Vietnam in general and Cuu Long delta area in particular, there are many studies analyzing the impact of infrastructure on economic development. Nguyễn Xuân Thành (2010) and Tran Minh Phuong (2012) have analyzed the constraints of infrastructure for socio-economic performance and thus affect growth outcomes. According to the authors, although Vietnam has been struggling to maintain a high level of infrastructural development in recent decades, the economy is still facing development challenges from weaknesses both in terms of quantity and quality of infrastructure.
The results of these studies also indicated that mobilizing and utilizing investment capital for development of infrastructure in Vietnam is ineffectiveness. In terms of infrastructure, transport infrastructure and power (electricity) infrastructure are the two weakest components hindering the process of industrialization, modernization and adversely affecting the business environment (Nguyễn Xuân Thành, 2010).

Although infrastructure for agricultural development in Cuu Long delta area has been invested and contributed to the agricultural sector of the region, there are still many limitations (Trân Hữu Hiệp, 2013). The Mekong delta is a region which is highly blessed with agricultural development, however, the barriers of infrastructure have hampered the capacity to exploit the advantages of the region for economic growth target. For example, rice production is the strength of Cuu Long delta area, but public infrastructures such as poor quality of irrigation systems and underdeveloped logistics systems have reduced the quality of products, thereby reducing the value of export products, which directly leads to a substantial decline in the competitiveness of products.

In addition, there are many inadequacies in the infrastructure development planning system (Thanh \& Dapice, 2009). The policy-makers often preferred road infrastructure (in planning the kind of traffic infrastructure) and prioritize the development of the North-South transport axis (in the traffic network planning). It leads to lack of synchronism, lack of connection and not suitable with the choice of industrial development in Vietnam. The lack of transport infrastructure (especially railways) to link the region, especially the East-West link, has limited the opportunities for spillover from the two growth poles of the country to the less developed regions and localities. The inadequacies of providing transport services, affecting business costs and competitiveness of enterprises, have been pointed out in this study. This is one of the many reasons for limiting the development of enterprises in Cuu Long delta area.

According to Blancas and El-Hifnawi (2014), river and sea transportation play an essential role in 
the economic development of Vietnam, in which the Cuu Long delta area has the advantage of developing these types of transportation. Over the last many years, the waterway infrastructure has not received adequate investment as other transportation infrastructure. It leads to a decline in the economic conditions and environmental sustainability of transportation modes.

Besides, the relationship between the design, construction, operation, exploitation of infrastructure and economic activities of households, enterprises, socio-economic development through quantitative analysis has been of high research interest (Van de Walle, 1996, 2003; Van de Walle \& Cratty, 2002; Glewwe et al., 2000; Nguyen, 2011). Studies have measured the impact of infrastructure on different dimensions of household and enterprises in Vietnam. Specifically, the research shows the positive impact of infrastructure in general or each type of infrastructure in particular to the income of the household, the income of workers, poverty reduction, and market development. The impact of infrastructure for households and enterprise is through: (1) improving labor productivity; (2) expanding development opportunities; (3) access to health and educational services; (4) access to clean water and energy, etc. However, most of the quantitative studies in the country focus on the impact of transport and irrigation infrastructure and not on other infrastructures such as energy, urban and telecommunications that can be compared with other studies in the world. In particular, there are not many studies that can assess the impact of road infrastructure on firm performance in general and on enterprises in Cuu Long delta area in particular.

One of the typical studies which assess the impact of infrastructure quality on firms was done by Escribano et al. (2010). The research applied micro-econometric techniques to evaluate the effect of infrastructure quality (e.g., energy, water, sanitation, transportation, telecommunications, and information and communications technology (ICT)) on the total factor productivity (TFP) of African manufacturing enterprises. The results of this study indicated that infrastructure quality had low positive impact on TFP for high-income countries and the negative impact on low-income countries. Besides,
Wan and Zhang (2017) also used econometric method to assess the direct and indirect impact of infrastructure on firm productivity in China. It is an empirical method that utilized largescale firm-level survey data. The main findings of the research indicated that all of infrastructures (road, telecommunications services, and cable) directly promote China's firm productivity and they had positive indirect impact on firm productivity through the agglomeration channel. Furthermore, there are also other empirical studies assessing the impact of infrastructure on economic growth and firm such as Reinikka and Svensson (2002), Bogetić and Olusi (2013), Moyo (2013), Mitra et al. (2016).

\section{METHODOLOGY AND DATA}

\subsection{Model}

According to Escribano et al. (2010) and Wan and Zhang (2017), Cobb-Douglas production function model is used to estimate the impact of road infrastructure on firm performance. Capital and labor, infrastructure enhancement index, size of firm, age of firm and business sector are taken into account, because those variables also affect business performance. Therefore, the regression to analyze the effect of road infrastructure on firms' performance in Cuu Long delta area is formulated as follows:

$$
\begin{aligned}
& Y_{i, j, k, t}=C_{t} \cdot f\left(K_{i, j, k, t}, L_{i, j, k, t}, X_{i, j, k, t},\right. \\
& \left.\operatorname{Inf}_{k, t}, \operatorname{Ind}_{i, j, k, t}\right),
\end{aligned}
$$

where $i, j, k, t$ - the firm, industry, province, and year, respectively, $C$ - constant, $Y$ - performance of enterprise, is proxy by firm's revenue, $K$ - the capital of enterprise, $L$ - the total employees of enterprise, $X$ - a vector of firm's characteristic control variables, including firm size based on amount of capital $(S)$, firm age $(A)$ which is measured by number of operational years since it was established), Inf - infrastructure enhancement index, proxy for enhancement quality of road infrastructure at specific province, Ind dummy variable reflecting the field of business. 
The abovementioned dummy variable includes $D_{1}, D_{2}, D_{3}, D_{4}$ :

$D_{1}$ - dummy variable for agriculture sector, $D_{1}$ takes value 1 if the registered field of business of the firm belongs to agriculture sector and value 0 if elsewhere; $D_{2}$ - dummy variable for industry sector, $D_{2}$ takes value 1 if the registered field of business of the firm belongs to industry sector and value 0 if elsewhere; $D_{3}$ - dummy variable for services sector, $D_{3}$ takes value 1 if the registered field of business of the firm belongs to services sector and value 0 if elsewhere; $D_{4}$ - dummy variable for construction sector, $D_{4}$ takes value 1 if the registered field of business of the firm belongs to construction sector and value 0 if elsewhere.

For empirical analysis, the above model (1) is transfered into the logarithm form as follows:

$$
\begin{aligned}
& \ln \left(Y_{i, j, k, t}\right)=\alpha_{0}+\alpha_{1} \ln \left(K_{i, j, k, t}\right)+ \\
& +\alpha_{2} \ln \left(L_{i, j, k, t}\right)+\alpha_{3} \ln \left(X_{i, j, k, t}\right)+ \\
& +\alpha_{4} \operatorname{Inf}_{k, t}+\alpha_{5} \operatorname{Ind}_{i, j, k, t}+u_{i, j, k, t},
\end{aligned}
$$

where $u$ is the random error term.

In addition to model (2), the authors use Granger causality model to test whether the road infrastructure is the cause of change in firm's performance.

\subsection{Data}

In this research, the authors use firm-level data from Annual Enterprises Survey by General Statistics Office of Vietnam (GSO). The data include informations of firm's performance (revenue), registered capital, number of employees, and other firm's characteristics (age, fields of business, firm size).

For assessing the impact of transport infrastructure enhancement on firm performance, we construct a road infrastructure indicator. There are no official serial statistical data related to the development/enhancement of transport infrastructure available. Some researchers used the length of roads, others use the total investment in infrastructure as a proxy for this indicator. Nevertheless, the overlaps of these data among provinces may cause bias in estimating the effect of road infrastructure on firm's performance.
This paper uses the sub-dimension on infrastructure of Provincial Competitiveness Index (PCI) as a proxy for the road infrastructure quality across provinces of Vietnam. The limitation of these data is, however, that they are only available from 2009 to 2011 .

After cleaning the data, the total number of observations is 24,064 .

\section{RESEARCH RESULTS}

In the models, adjusted $R 2$ of approx. 0.59 with their corresponding $p$-value of $0.0000<.05 \mathrm{im}$ plies that the main inputs $(K, L)$, firm's characteristics (age and firm size) and road infrastructure could explain less than 59\% of the variations of the firm's performance.

The result shows that capital and labor are the major determinant factors of firm's performance. Among firm's characteristics, only firm's age has a positive impact on firm's performance. Firm size has a negative impact on firm's performance in Cuu Long delta area. This can be explained in Cuu Long delta area in that service businesses accounts for the majority of the number of enterprises (accounting for more than 63\%). Service enterprises do not need a lot of fixed assets, inventory, high technology, so they do not need much capital. Therefore, their turnover does not depend on the size of their capital. As a recommendation, this is also a problem that the authors need to study in the near future.

The road infrastructure has significant impacts on firm's performance, but the level of impacts is lower for enterprises in construction and industry sectors and higher for group of firms in service and agriculture sectors. Service enterprises usually do business in the field of transportation, logistics, tourism, etc., which often use road infrastructure for business activities. Therefore, service enterprises are the largest beneficiaries of road infrastructure.

The results are supported by the characteristics of these business sectors. In order to save cost, construction enterprises often prefer waterway to road infrastructure for moving materials due to 
Table 1. Final estimation result of model (2) with different dummy variables

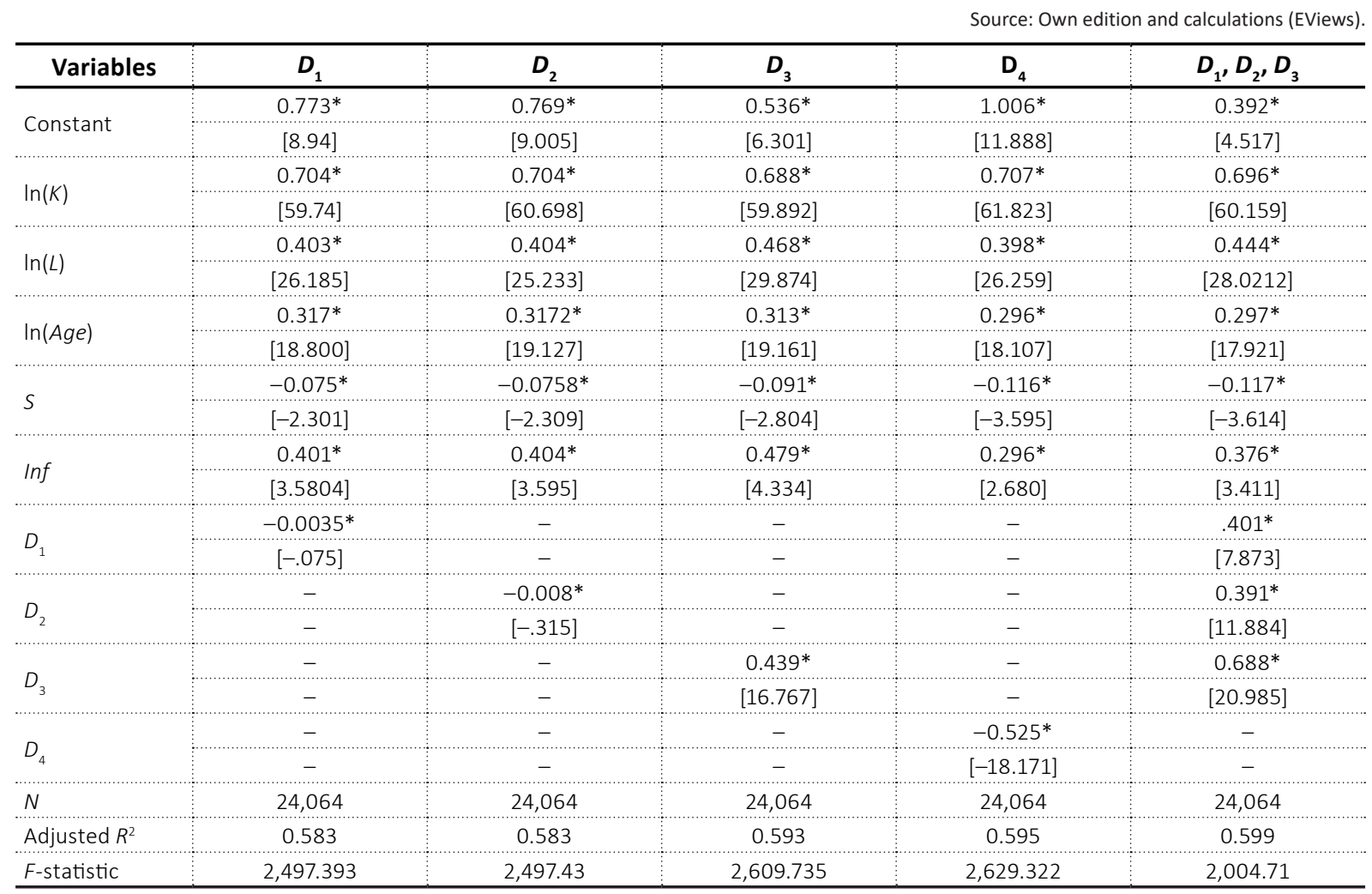

Note: * is statistically significant at 0.01; explained variable is In (revenue).

the fact that waterway transportation infrastructure could carry larger volume and the materials do not require the strict time of transportation. Therefore, road infrastructure has a small impact on the performance of these construction firms in comparison with enterprises in other sectors.

The agriculture sector in this area is specializing in food processing, including rice, shrimp, fish processing. In addition, there are some areas specializing in tropical fruits and vegetables. In shipping perishable products to the markets, like tropical fruits and vegetables, enterprises often utilize air-condition trucks and prefer good quality road infrastructure. For the other kinds of agricultural products, they prefer waterway infrastructure for their quantity is often larger than the road infrastructure could handle. Therefore, road infrastructure has positive impacts on agribusiness enterprises' performance and the level of impacts is higher than that of construction enterprises' performance.

For industry and service sector, road infrastructure plays a significant role, as the result shows that for these products, which need to be transported by road infrastructure to the market (in case of manufacturing sector), the road infrastructure facilitates them to access to customers easily.

The results in Table 1 also imply that capital and labor are two main factors that contribute to firm's performance and that capital has greater impacts on the performance of firms, compared with that of labor. Enterprises in Cuu Long delta area are still relying on the resource-based growth model, especially capital expansion for growth. Although government urges enterprises and local economy to restructure since 2011, shifting from resource-based growth model to knowledge and innovation-based growth model. Such results show that Cuu Long delta area economy still has much to do to get rid of resource-based growth model. In other words, it is the biggest challenge for this region in fostering knowledge and innovation-based enterprises in order to achieve more sustainable economic development.

On the one hand, the experience of the enterprises (firm age) also makes a significant contribution to the performance of the firms, with small differ- 
Table 2. Test of road infrastructure in terms of its significant role boosting the firm performance in Cuu Long delta area by using VAR Granger causality model

Source: Own edition and calculations (EViews).

\begin{tabular}{l|c|c|c|c}
\hline \multicolumn{1}{c}{ Causality test } \\
\hline \multicolumn{1}{c}{ Granger causality } & Lags & $\begin{array}{c}\text { Infrastructure enhancement } \\
\text { index } \rightarrow \text { firm's revenue }\end{array}$ & $\begin{array}{c}\text { Firm's revenue } \rightarrow \text { infrastructure } \\
\text { enhancement index }\end{array}$ & Test \\
\hline $\begin{array}{l}\text { Infrastructure enhancement } \\
\text { index } \rightarrow \text { firm's revenue }\end{array}$ & 2 & $\begin{array}{c}29.34 \\
(0.0000)^{*}\end{array}$ & $\begin{array}{c}18.83 \\
(0.0000)^{*}\end{array}$ & VAR model \\
\hline
\end{tabular}

Note: By VAR model, the authors present the F-tests of zero restrictions, the $p$-value is in parentheses; * shows $5 \%$ significance level.

ence across field of business, although the level of impacts is lower in comparison with that of capital $(K)$ and labor $(L)$ factors. On the other hand, firm size has negative impacts on firm's performance (statistically significant). In this situation, more research is needed to examine whether the size of the firm is approaching its optimal size or not?

Besides, in order to analyze or determine the significance of road infrastructure for boosting the firm performance in Cuu Long delta area, the authors used VAR Granger causality model to test it. This is the type of model, which indicates causes and results. By using this method, the authors examined whether infrastructure enhancement index is the cause of firm's revenue.

Based on the result above, we can observe that the value of Chi-square statistic is 57.4799 , and its corresponding $p$-value is $0.0000<0.05$. Since the $p$-value is less than 0.05 , we can conclude that road infrastructure causes firm performance in Cuu Long delta area. Therefore, localities in the region need to invest and improve the quality of road infrastructure to improve the efficiency of enterprises.

\section{CONCLUSION}

This paper investigates the effect of road infrastructure on firm performance in Cuu Long delta area. The results shows that enhancing road infrastructure will effectively help to enhance the performance of the firms. The impact of road and transportation infrastructure on firm's performance quite varies, higher in agriculture and service sectors and lower in industry and construction sectors.

The results also suggest that firm's performance is much reliant on capital and labor factors, and this characteristics of firms in Cuu Long delta area lead us to an inference that the economy of this region is still based on resource-based growth model, and the region needs more efforts to shift into knowledge-based growth model. Besides, to create incentives for firms to exploit an absolute advantage of this region in agriculture and waterway transportation, infrastructural investment among modes of transportation (e.g., waterway, road, rail-road, and airway) should be reconsidered.

Transport infrastructure has a significant role in the economy, regions, and enterprises. Therefore, evaluating the impact of transport infrastructure for the above objects is a critical research content. In the future, the scholars can study and assess the effect of transport infrastructure on household, region or economy level. Besides, scholars can analyze the impact of choosing the transportation mode on firm performance. The results of these studies will be very useful for the government, policy-makers and enterprises.

\section{ACKNOWLEDGEMENT}

This research is supported by Program of Science and Technology for Sustainable Development in Cuu Long delta area (KHCN-TNB/14-19/X13). 


\section{REFERENCES}

1. Albarran, P., Carrasco, R., \& Holl, A. (2011). Domestic Transport Infrastructure and Firms' Export Market Participation. Small Business Economics, 40(4), 879-898. Retrieved from https://www.jstor. org/stable/43552837?seq=1\#page_ scan_tab_contents

2. Blancas, L. C., \& El-Hifnawi, M. B. (2013, December). Facilitating Trade Through Competitive, LowCarbon Transport: The Case for Vietnam's Inland and Coastal Waterways (World Bank). https://doi. org/10.1596/978-1-4648-0105-1

3. Bogetić, Ž., \& Olusi, O. (2013). Drivers of firm-level productivity in Russia's manufacturing sector (Policy Research Working Paper No. 6572). World Bank, Washington, DC. https://doi.org/10.1596/18139450-6572

4. Calderon, C., \& Serven, L. (2004). The Effects of Infrastructure Development on Growth and Income Distribution (The World Bank Policy Research Working Paper Number 3400). https://doi. org/10.1596/1813-9450-3400

5. Escribano, A., Guasch, J. L., \& Pena, J. (2010). Assessing the impact of infrastructure quality on firm productivity in Africa: cross-country comparisons based on investment climate surveys from 1999 to 2005 (Policy Research Working Paper No. 5191). World Bank, Washington, DC. https://doi. org/10.1596/1813-9450-5191

6. Fay, M., Toman, M., Benitez, D., \& Csordas, S. (2010, June). Infrastructure and Sustainable Development. In Proceedings of Korea-World Bank Conference on Post-Crisis Economic Development. Busan.

7. Garcia-Puente, M. Paloma Alonso (2013). Infrastructure policy unit: 2012 PPI data update: transport sector (English) (note no. 87). PPI data update. Washington, D.C.: World Bank Group. Retrieved from http://documents.worldbank.org/curated/ en/177741495091866214/Infrastructure-policy-unit-2012-PPIdata-update-transport-sector
8. General Statistics Office of Vietnam (GSO) (n.d.). Available at https://www.gso.gov.vn/

9. Glewwe, P., Zaman, H., \& Gragnolati, M. (2000). Who gained from Vietnam's boom in the 1990s? An analysis of poverty and inequality trends. The World Bank.

10. Helpman, E., \& Krugman, P. (1985). Market Structure and Foreign Trade Increasing Returns, Imperfect Competition, and the International Economy. Cambridge, MA: MIT Press. Retrieved from https://books.google.com. vn/books?hl=vi\&lr=\&id=KB_bO $8 \mathrm{w} 4$ JgoC\&oi=fnd\&pg $=$ PR11\&dq $=$ Market + Structure + and + Foreign +Trade+Increasing+Returns, +Im perfect+Competition, + and + the+ International + Economy\&ots $=\mathrm{dF}$ styrU_RX\&sig=kTiAuSE5fiitCP_ fhbPoikVeOws\&redir esc $=\mathrm{y} \# \mathrm{v}=$ onepage $\& \mathrm{q}=$ Market $\% 20$ Structure\%20and\%20Foreign $\% 20$ Trade $\% 20$ Increasing\% 20 Returns\%2C\%20Imperfect\%20 Competition\%2C\%20and\%20 the $\% 20$ International\%20 Economy $\& \mathrm{f}=$ false

11. Holl, A. (2006). A Review of the Firm-Level Role of Transport Infrastructure with Implications for Transport Project Evaluation. Journal of Planning Literature, 21(1), 3-14. https://doi.org/10.1177\%2F0885412206288905

12. Kingsley, T. (2004). The Role of Infrastructure in Development. Bank of Jamaica.

13. Lê Khương Ninh, Nguyễn Lê Hoa Tuyết, Huỳnh Hũu Thọ (2011). Ảnh hưởng của quy hoạch treo đến tình trạng nghèo đói ở vùng ven đô thị Đồng bằng sông Cửu Long [Impact of suspension planning on poverty in suburban areas in Cuu Long delta area]. Tap chí Phát triên kinh tế, 245, 36-42. Retrieved from http://www.vjol. info/index.php/PTKT/article/ view/35042

14. Lensink, R., \& Van Nam, M. (2008, December). Economic Development of the Mekong Delta in Vietnam (CDS Research Paper No. 27).
Retrieved from https://www.rug. nl/research/portal/files/2703531/ CDS-27.pdf

15. Lozano-Oyola, M., Blancas, F. J., González, M., \& Caballero, R. (2012, July). Sustainable tourism indicators as planning tools in cultural destinations. Ecological Indicators, 18, 659-675. https://doi org/10.1016/j.ecolind.2012.01.014

16. Márquez-Ramos, L. (2015, May). The relationship between trade and sustainable transport: A quantitative assessment with indicators of the importance of environmental performance and agglomeration externalities. Ecological Indicators, 52, 170-183. https://doi. org/10.1016/j.ecolind.2014.11.023

17. Mitra, A., Varoudakis, A., \& Véganzonès-Varoudkis, M. (2002, January). Productivity and technical efficiency in Indian states' manufacturing: the role of infrastructure. Economic Development and Cultural Change, 50(2), 395-426. https://doi.org/10.1086/321916

18. Moyo, B. (2013). Power infrastructure quality and manufacturing productivity in Africa: a firm level analysis. Energy Policy, 61, 10631070. https://doi.org/10.1016/j. enpol.2013.05.111

19. Nguyễn Ngọc Anh (2011). Quy hoạch tổng thể thủy lợi đồng bằng sông Cửu Long trong điều kiện biến đổi khí hậu- nước biển dâng. Viện quy hoạch thủy lợi miền Nam.

20. Nguyễn Thế Bình (2015). Nông nghiệp vùng đông bằng sông Cửu Long: thực trạng, cơ hội và thách thức trong bối cảnh hội nhập. Kỷ yếu hội thảo "Nông nghiệp vùng Đồng bằng sông Cửu Long thực trạng, cơ hội và thách thức trong bối cảnh hội nhập", Phân viện Qui hoạch và thiết kế nông nghiệp.

21. Nguyễn Xuân Thành (2010). Những trở ngại về cơ sở ha tâng của Việt Nam. Tài liệu đối thoai chính sách số 1 , Chương trình Phát triển Liên hợp quốc tại Việt Nam. Retrieved from http://101.99.50.98:8080/dspace/ bitstream/TVDHKT/716/1/ LH0087.pdf 
22. Nguyen, V. C. (2011). Estimation of the Impact of Rural Roads on Household Welfare in Viet Nam. Asia-Pacific Development Journal, 18(2), 105-135. https://doi. org/10.18356/e934162d-en

23. Reinikka, R., \& Svensson, J. (2002). Coping with poor public capital. Journal of Development Economics, 69(1), 51-69. https://doi.org/10.1016/S03043878(02)00052-4

24. Tạp chí tài chính (Review of Finance) (2018). Phát triên vùng Đông bằng sông Cửu Long theo hướng tăng trưởng xanh. Retrieved from http://tapchitaichinh.vn/ nghien-cuu-trao-doi/phat-trienvung-dong-bang-song-cuulong-theo-huong-tang-truongxanh-133372.html

25. Tho D. Nguyen (2009). Place Development: Attributes and Business Customer Satisfaction in Tien Giang Province, Vietnam. Journal of Macromarketing, 29(4), 384-391. https://doi. org/10.1177/0276146709346254

26. Thanh, N. X., \& Dapice, D. (2009). Vietnam's infrastructure constraints. Cambridge: United Nations Development Programme. Retrieved from https://ash. harvard.edu/links/vietnams-infrastructure-constraints

27. Tổng cục Thủy lợi (Directorate of Water resources) (2014). Thủy lợi phục vụ nuôi trồng thủy sản và phát triển nông nghiệp bền vững vùng ven biển đông bằng sông Cửu Long. Tại hội thảo “Tái cơ cấu phát triển nông nghiệp gắn xây dựng nông thôn mới thích ứng với biến đổi khí hậu vùng đòng bằng sông Cửu Long”. Sóc Trăng.

28. Trần Hữu Hiệp (2013). Một số vấn đề về phát triển vùng và mối liên kết vùng đông bằng sông Cửu Long. Kỷ yếu hội thảo Giải pháp khai thác tiềm năng Kinh tế-xã hội các tỉnh đông bằng sông Cửu Long theo hướng liên kết vùng, trang 1-7. Retrieved from http:// thuviencantho.vn/DataLibrary/ Images/MOT\%20SO\%20VAN\%20 DE\%20VE\%20PHAT\%20 TRIEN\%20VUNG\%20VA\%20 LIEN\%20KET\%20VUNG\%20 DBSCL.pdf

29. Tran Minh Phuong (2012). Phát triển kết cấu hạ tầng giao thông đáp ứng yêu cầu công nghiệp hóa, hiện đại hóa ở Việt Nam. Luận án Tiến sĩ, Viện Chiến lược phát triển.

30. UNDP (1992). Human development report 1992. Retrieved from http://hdr.undp.org/sites/default/ files/reports/221/hdr_1992_en_ complete_nostats.pdf

31. Van de Walle, D. (1996). Infrastructure and Poverty in Vietnam. The World Bank, Washington, D.C. Retrieved from https://elibrary. worldbank.org/doi/abs/10.1596/08213-3544-8

32. Van de Walle, D. (2003). Are Returns to Investment Lower for the Poor? Human and Physical Capital Interactions in Rural Vietnam (World Bank Working Paper 2425). Washington, D.C. Retrieved from https://onlinelibrary.wiley.com/ doi/abs/10.1111/1467-9361.00214

33. Van de Walle, D., \& Cratty, D. (2002). Impact Evaluation of a Rural Road Rehabilitation Project. World Bank, Washington D.C. Processed. Retrieved from http:// citeseerx.ist.psu.edu/viewdoc/dow nload?doi $=10.1 \cdot 1 \cdot 201.6126 \& \mathrm{rep}=\mathrm{r}$ ep $1 \&$ type $=$ pdf

34. VCCI (2012). Báo cáo thường niên doanh nghiệp Việt Nam 2011: Liên kết kinh doanh. Nhà xuất bản Thông tin và Truyền thông.

35. Vietnam Chamber of Commerce and Industry (VCCI). Available at http://vcci.com.vn/

36. Watson, Farley, \& Williams (2009) Infrastructure development in Vietnam - Briefing.

37. World Bank (1994). Infrastructure for Development. World Development Report.

38. Yoshio, N., \& Nakahigashi, M. (2000). The Role of Infrastructure in Economic Development. Keio University. 


\section{APPENDIX A}

Table A1. Descriptive statistics of the data

\begin{tabular}{|c|c|c|c|c|c|}
\hline Variables & $\begin{array}{c}\text { Number of } \\
\text { observations }\end{array}$ & Mean & Standard deviation & Minimum value & Maximum value \\
\hline Revenue & 24,067 & 35125.34 & 96827.42 & .000 & 1054147 \\
\hline$K$ & 24,067 & 23294.93 & 70265.76 & 3.362 & 1301322 \\
\hline$L$ & 24,067 & 54.071 & 103.25 & 11 & 1131 \\
\hline Age & 24,067 & 4.95 & 4.308 & 1 & 54 \\
\hline $\operatorname{lnf}$ & 24,067 & .35 & .106 & .11 & .547 \\
\hline
\end{tabular}

Table A2. Estimation result of model (2) with $D_{1}, D_{2}$ and $D_{3}$

Dependent variable: In (revenue)

Method: least squares

Date: 08/08/18 Time: 21:31

Sample (adjusted): 24,067

Included observations: 10,729 after adjustments

\begin{tabular}{|c|c|c|c|c|}
\hline Variables & Coefficient & Std. error & t-statistic & Prob. \\
\hline C & 0.392449 & 0.086884 & 4.516940 & 0.0000 \\
\hline $\ln (K)$ & 0.695809 & 0.011566 & 60.15926 & 0.0000 \\
\hline $\ln (L)$ & 0.443588 & 0.015830 & 28.02124 & 0.0000 \\
\hline $\ln ($ Age $)$ & 0.297625 & 0.016608 & 17.92068 & 0.0000 \\
\hline$S$ & -0.116683 & 0.032288 & -3.613864 & 0.0003 \\
\hline $\operatorname{lnf}$ & 0.376184 & 0.110281 & 3.411127 & 0.0006 \\
\hline$D_{1}$ & 0.401068 & 0.050940 & 7.873341 & 0.0000 \\
\hline$D_{2}$ & 0.390785 & 0.032882 & 11.88438 & 0.0000 \\
\hline$D_{3}$ & 0.687901 & 0.032780 & 20.98530 & 0.0000 \\
\hline$R$-squared & 0.599367 & \multicolumn{2}{|c|}{ Mean dependent var } & 8.723860 \\
\hline Adjusted $R$-squared & 0.599068 & \multicolumn{2}{|c|}{ S.D. dependent var } & 1.939294 \\
\hline S.E. of regression & 1.227945 & \multicolumn{2}{|c|}{ Akaike info criterion } & 3.249400 \\
\hline Sum squared resid & 16164.14 & \multicolumn{2}{|c|}{ Schwarz criterion } & 3.255507 \\
\hline Log likelihood & -17422.40 & \multicolumn{2}{|c|}{ Hannan-Quinn criter. } & 3.251460 \\
\hline F-statistic & 2004.710 & \multicolumn{2}{|c|}{ Durbin-Watson stat } & 1.218947 \\
\hline Prob (F-statistic) & 0.000000 & \multicolumn{2}{|c|}{-} & - \\
\hline
\end{tabular}

Table A3. Estimation result of model (2) with $D_{1}$

\begin{tabular}{|c|c|c|c|c|}
\hline \multicolumn{5}{|c|}{ Dependent variable: In (revenue) } \\
\hline \multicolumn{5}{|c|}{ Method: least squares } \\
\hline \multicolumn{5}{|c|}{ Date: 08/08/18 Time: 21:38 } \\
\hline \multicolumn{5}{|c|}{ Sample (adjusted): 24,067 } \\
\hline \multicolumn{5}{|c|}{ Included observations: 10,729 after adjustments } \\
\hline Variables & Coefficient & Std. error & t-statistic & Prob. \\
\hline C & 0.773149 & 0.086517 & 8.936395 & 0.0000 \\
\hline $\ln (K)$ & 0.704243 & 0.011789 & 59.73760 & 0.0000 \\
\hline $\ln (L)$ & 0.403127 & 0.015395 & 26.18575 & 0.0000 \\
\hline $\ln ($ Age $)$ & 0.317892 & 0.016909 & 18.80003 & 0.0000 \\
\hline$S$ & -0.075649 & 0.032878 & -2.300898 & 0.0214 \\
\hline $\operatorname{lnf}$ & 0.400961 & 0.111987 & 3.580426 & 0.0003 \\
\hline$D_{1}$ & -0.003530 & 0.047109 & -0.074937 & 0.9403 \\
\hline$R$-squared & 0.582905 & \multicolumn{2}{|c|}{ Mean dependent var } & 8.723860 \\
\hline Adjusted R-squared & 0.582671 & \multicolumn{2}{|c|}{ S.D. dependent var } & 1.939294 \\
\hline S.E. of regression & 1.252803 & \multicolumn{2}{|c|}{ Akaike info criterion } & 3.289296 \\
\hline Sum squared resid & 16828.35 & \multicolumn{2}{|c|}{ Schwarz criterion } & 3.294047 \\
\hline Log likelihood & -17638.43 & \multicolumn{2}{|c|}{ Hannan-Quinn criter. } & 3.290899 \\
\hline F-statistic & 2497.393 & \multicolumn{2}{|c|}{ Durbin-Watson stat } & 1.194607 \\
\hline Prob (F-statistic) & 0.000000 & \multicolumn{2}{|c|}{-} & - \\
\hline
\end{tabular}


Table A4. Estimation result of model (2) with $D_{2}$

\begin{tabular}{|c|c|c|c|c|}
\hline \multicolumn{5}{|c|}{ Dependent variable: In (revenue) } \\
\hline \multicolumn{5}{|c|}{ Method: least squares } \\
\hline \multicolumn{5}{|c|}{ Date: 08/08/18 Time: 21:40 } \\
\hline \multicolumn{5}{|c|}{ Sample (adjusted): 24,067 } \\
\hline \multicolumn{5}{|c|}{ Included observations: 10,729 after adjustments } \\
\hline Variables & Coefficient & Std. error & t-statistic & Prob. \\
\hline C & 0.769121 & 0.085412 & 9.004878 & 0.0000 \\
\hline $\ln (K)$ & 0.704427 & 0.011605 & 60.69820 & 0.0000 \\
\hline $\ln (L)$ & 0.404583 & 0.016034 & 25.23319 & 0.0000 \\
\hline $\ln ($ Age $)$ & 0.317269 & 0.016588 & 19.12687 & 0.0000 \\
\hline$s$ & -0.075801 & 0.032815 & -2.309962 & 0.0209 \\
\hline $\operatorname{lnf}$ & 0.404460 & 0.112501 & 3.595177 & 0.0003 \\
\hline$D_{2}$ & -0.008457 & 0.026806 & -0.315507 & 0.7524 \\
\hline R-squared & 0.582908 & \multicolumn{2}{|c|}{ Mean dependent var } & 8.723860 \\
\hline Adjusted R-squared & 0.582675 & \multicolumn{2}{|c|}{ S.D. dependent var } & 1.939294 \\
\hline S.E. of regression & 1.252798 & \multicolumn{2}{|c|}{ Akaike info criterion } & 3.289288 \\
\hline Sum squared resid & 16828.20 & \multicolumn{2}{|c|}{ Schwarz criterion } & 3.294038 \\
\hline Log likelihood & -17638.38 & \multicolumn{2}{|c|}{ Hannan-Quinn criter. } & 3.290890 \\
\hline F-statistic & 2497.430 & \multicolumn{2}{|c|}{ Durbin-Watson stat } & 1.194751 \\
\hline Prob (F-statistic) & 0.000000 & \multicolumn{2}{|c|}{-} & - \\
\hline
\end{tabular}

Table A5. Estimation result of model (2) with $D_{3}$

Dependent variable: In (revenue)

Method: least squares

Date: 08/08/18 Time: 21:42

Sample (adjusted): 24,067

Included observations: 10,729 after adjustments

\begin{tabular}{|c|c|c|c|c|}
\hline Variables & Coefficient & Std. error & t-statistic & Prob. \\
\hline C & 0.535792 & 0.085032 & 6.301077 & 0.0000 \\
\hline $\ln (K)$ & 0.688472 & 0.011495 & 59.89222 & 0.0000 \\
\hline $\ln (L)$ & 0.468477 & 0.015682 & 29.87451 & 0.0000 \\
\hline $\ln (A g e)$ & 0.313046 & 0.016337 & 19.16149 & 0.0000 \\
\hline$S$ & -0.090881 & 0.032406 & -2.804481 & 0.0050 \\
\hline $\operatorname{lnf}$ & 0.479480 & 0.110640 & 4.333700 & 0.0000 \\
\hline$D_{3}$ & 0.439883 & 0.026234 & 16.76753 & 0.0000 \\
\hline$R$-squared & 0.593562 & \multicolumn{2}{|c|}{ Mean dependent var } & 8.723860 \\
\hline Adjusted $R$-squared & 0.593335 & \multicolumn{2}{|c|}{ S.D. dependent var } & 1.939294 \\
\hline S.E. of regression & 1.236694 & \multicolumn{2}{|c|}{ Akaike info criterion } & 3.263413 \\
\hline Sum squared resid & 16398.36 & \multicolumn{2}{|c|}{ Schwarz criterion } & 3.268163 \\
\hline Log likelihood & -17499.58 & \multicolumn{2}{|c|}{ Hannan-Quinn criter. } & 3.265015 \\
\hline F-statistic & 2609.735 & \multicolumn{2}{|c|}{ Durbin-Watson stat } & 1.207049 \\
\hline Prob (F-statistic) & 0.000000 & & & \\
\hline
\end{tabular}


Table A6. Estimation result of model (2) with $D_{4}$

Dependent variable: In (revenue)

Method: least squares

Date: 08/08/18 Time: 21:46

Sample (adjusted): 24,067

Included observations: 10,729 after adjustments

\begin{tabular}{|c|c|c|c|c|}
\hline Variables & Coefficient & Std. error & $t$-statistic & Prob. \\
\hline C & 1.006445 & 0.084661 & 11.88793 & 0.0000 \\
\hline $\ln (K)$ & 0.706705 & 0.011431 & 61.82277 & 0.0000 \\
\hline $\ln (L)$ & 0.398061 & 0.015159 & 26.25929 & 0.0000 \\
\hline $\ln ($ Age $)$ & 0.295911 & 0.016342 & 18.10688 & 0.0000 \\
\hline$S$ & -0.116487 & 0.032399 & -3.595449 & 0.0003 \\
\hline $\operatorname{lnf}$ & 0.296016 & 0.110447 & 2.680164 & 0.0074 \\
\hline$D_{4}$ & -0.525558 & 0.028924 & -18.17053 & 0.0000 \\
\hline$R$-squared & 0.595365 & \multicolumn{2}{|c|}{ Mean dependent var } & 8.723860 \\
\hline Adjusted $R$-squared & 0.595138 & \multicolumn{2}{|c|}{ S.D. dependent var } & 1.939294 \\
\hline S.E. of regression & 1.233949 & \multicolumn{2}{|c|}{ Akaike info criterion } & 3.258968 \\
\hline Sum squared resid & 16325.63 & \multicolumn{2}{|c|}{ Schwarz criterion } & 3.263718 \\
\hline Log likelihood & -17475.73 & \multicolumn{2}{|c|}{ Hannan-Quinn criter. } & 3.260570 \\
\hline F-statistic & 2629.322 & \multicolumn{2}{|c|}{ Durbin-Watson stat } & 1.212310 \\
\hline Prob (F-statistic) & 0.000000 & \multicolumn{2}{|c|}{-} & - \\
\hline
\end{tabular}

Table A7. Granger causality tests

Pairwise Granger causality tests

Date: 08/08/18 Time: 21:33

Sample: 24,067

Lags: 2

\begin{tabular}{l|c|c|c}
\multicolumn{1}{c|}{ Null hypothesis } & Obs & F-statistic & Prob. \\
\hline In (revenue) does not Granger cause Inf & 23,993 & 18.8324 & 29.3421 \\
\hline Inf does not Granger cause In (revenue) & & $2 . \mathrm{E}-09$ \\
\hline
\end{tabular}

